\title{
Exogenous Shocks in Subsystem Adjustment and Policy Change: The Credit Crunch and Canadian Banking Regulation
}

\author{
RUSSELL ALAN WILLIAMS Political Science, \\ Memorial University of Nerefoundland
}

\begin{abstract}
This paper explores the impact of internationalization on the financial services policy subsystem in Canada. It uses subsystem adjustment as a concept to bring some analytical clarity to how exogenous factors like globalisation and international crises may impact existing policy regimes. Based on examination of globalisation-induced banking deregulation (I987-I99I) and the current crisis of securitized banking, the paper argues that the strength of this approach is that it integrates endogenous effects of the existing subsystem in explaining policy changes in response to what are normally treated as exogenous shocks. Careful effort needs to be made to differentiate the processes of external systemic perturbations from subsystem spillovers as these two processes of adjustment and policy change can lead to different policymaking dynamics over the long term.
\end{abstract}

Key words: Financial Services Regulation, Subsystem Adjustment, Banking, Globalisation, Canada.

Banking is a wonderful business to be in if you just don't blow yourself up every five to seven years.

Ed Clark, Toronto Dominion Bank President, 2008. ${ }^{\mathrm{I}}$

Subsystem analysis and exogenous-driven policy change

Contemporary policy process scholarship is notable for two trends. A range of approaches emphasize the importance of policy subsystems, which tend to see policymaking in traditionally incremental terms, as entrenched policy elites, variously seen as networks, communities etc. promote stability in policy outcomes. These subsystem approaches have been particularly popular in Canadian policy analysis (Skogstad 2000, Coleman and Perl i999). At the same time, there has been a tendency in the last twenty years to see substantive policy change as being driven by factors exogenous to the normal policymaking dynamics of a subsystem - whether through social learning (Hall i993), punctuated equilibriums (Baumgartner and Jones 1993) or through some sort of 
exogenous systemic perturbation or shock (Howlett and Ramesh 2002). Reconciling these two orthodox views is a kind of generalized Kuhnian schema in which periods of subsystem normal politics promoting inertia are punctured by these exogenous shocks which generate rapid policy change and often reconfigurations of the policy subsystem itself. Problematically, aside from the fact that this places the drivers of substantive policy change outside of the policy subsystem (and thus undermines the value of the current obsession with subsystems) it has also led to a knee jerk sense that the shock which disturbs normal politics in a policy domain is exogenous. Basically, this crude schema has led scholars to underplay the endogenous factors in a policy subsystem which impact both the perception of the external shock, and the ultimate changes to the policy regime that will emerge in response to that shock (Howlett and Cashore, 2007). The nature of a punctuated equilibrium has a great deal more to do with endogenous factors than is often suggested.

This paper explores this problem through subsystem adjustment analysis: a proposed typology to clarify the interplay of factors associated with globalisation (as a particular exogenous perturbation) and existing policy subsystems in explaining policy change. In particular it explores the differences between a systemic perturbation and a subsystem spillover, two types of subsystem adjustment in the Canadian financial services sector. The paper argues that the strength of the subsystem adjustment concept is that the nature of adjustment and policy change is driven in part by considerations internal to the subsystem, the policy goals of existing key actors, and their perceptions of the lessons provided by exogenous developments. Careful effort needs to be made to differentiate subsystem spillovers from systemic perturbations as these two processes of adjustment and policy change can lead to different policymaking dynamics over the long term.

\section{Globalisation and subsystem adjustment - systemic perturbations and policy spillovers}

Many pieces on globalisation and public policy generally, and financial services specifically, note that whatever the exogenous forces driving policy change, ultimately domestic subsystems and domestic institutions impact the specific policy responses to those forces (Skogstad 2000, Bernstein and Cashore 2000 and Quaglia 2008). However, there is little in the way of a systematic analytical response to this problem. How do we integrate macro social processes like globalisation and policy subsystem considerations in explaining the nature of policy change? Howlett and Ramesh (2002) argue that globalisation has most commonly been seen as a kind of intrusion of external elements into stable 'homeostatic' policy 
subsystems. However, they suggest that policy subsystems need to be understood in an adaptive sense, in which these exogenous effects stimulate subsystem change and reconfigure policymaking along lines that vary from one setting to another, depending on the nature of the existing subsystem. This requires the development of a subsystem adjustment model if we want to understand the dynamics of policy change. Howlett and Ramesh identify four types of subsystem adjustment where considerations captured by the existing notions of a policy subsystem interact with exogenous factors in producing new policy regimes. These include, policy learning, venue change, systemic perturbations and subsystem spillovers. In the case of policy learning (Heclo I974, Bennett I99i) and venue change (Baumgartner and Jones I99I, I993) actors endogenous to the existing subsystem use exogenous factors such as information gathered from other jurisdictions or access to previously unavailable policy forums/processes to pursue desired policy goals. In these cases, although policy change relates to exogenous factors, it is immediately clear that that change is initiated and subsequently managed in large part by the goals and strategies of actors internal to the subsystem (See Table I).

External systemic perturbations and subsystem spillovers are more problematic and require more case studies to illustrate the interactive effect of globalisation and policy subsystems to explain patterns of policy change - more effort is required to clearly distinguish and operationalize these concepts. In particular more effort needs to made to tease out hypotheses about how these two change processes will affect policymaking over the long term.

None the less, systemic perturbations can be seen generally as external events which draw new attention to a policy sector (Sabatier and Weible 2007). Normally this includes things like floods, changes in political regimes, or in the case of financial services, financial crises. Such 'Crises afford enhanced opportunities to policymakers, because they are required to look beyond routine and there is often not the time for extensive

Table i. Subsystem Adjustment Processes Associated with Internationalization

\begin{tabular}{|c|c|c|c|}
\hline & & \multicolumn{2}{|l|}{ Nature of Adjustment } \\
\hline & & $\begin{array}{l}\text { New } \\
\text { Actors/Institutions }\end{array}$ & New Policy Ideas \\
\hline \multirow{2}{*}{ Initiator of Policy Change } & Endogenous - Actor Driven & Venue Change & Policy Learning \\
\hline & $\begin{array}{l}\text { Exogenous - (Shocks etc. })- \\
\text { Actors respond }\end{array}$ & $\begin{array}{l}\text { Subsystem } \\
\text { Spillovers }\end{array}$ & $\begin{array}{l}\text { Systemic } \\
\text { Perturbation }\end{array}$ \\
\hline
\end{tabular}


consultations or for opposition to change to build up' (Howlett and Ramesh 2002). Crises bring new actors or new ideas and policy goals to the forefront of policymaking and can produce dynamic policy change. While Howlett and Ramesh are not specific about these dynamics, it seems clear that such a crisis can strengthen the hand of some actors to pursue desired policy goals while weakening others. However crisis-generated policy change need not alter the fundamental nature of the subsystem over the long term as once a response to the crisis is generated, the basic membership of the subsystem need not have been radically altered.

Subsystem spillovers are far more complex and there have been few case studies exploring the dynamics of this type of subsystem adjustment. Much like a systemic perturbation a subsystem spillover is generated by exogenous factors. However these exogenous developments promote the merging or integration of previously separate subsystems into a single policy domain. An example might be when environment and industrial policy interact in response to climate change concerns or aboriginal and resource policy domains interact in response to legal questions of aboriginal land rights. Effectively a spillover can produce an entirely new 'uber' policy subsystem in which there are now new institutions and a new mix of actors - which in the short term should be conducive to policy change. Unlike a systemic perturbation, policy struggles tend to still be dominated by interested parties (rather than perhaps broad public awareness related to the 'crisis'), but by bringing together previously separate subsystems, policymaking dynamics can be quite confused.

Three considerations seem important here. First, from a subsystem adjustment perspective the pattern of policy change in each of these two processes is still going to be highly dependent on the goals and strategies of actors inside the subsystem. While these may be exogenously triggered processes of policy change, ultimately it is the subsystem that adjusts to produce policy responses and as researchers we need to avoid the temptation to treat these event as 'unusual shocks' and therefore exceptions to the 'normal politics' of the sector. It is often overlooked, but as Nohrstedt (2008) illustrates not all exogenous shocks lead to policy change; and even in extremely important shocks (in his case, the impact of Chernobyl on nuclear energy policy) policy responses have far more to do with endogenous factors. To understand policy change we should integrate factors associated with normal politics and the exogenous events to try to predict likely patterns of response.

Second, it seems clear that if we follow Howlett and Ramesh's logic, these two types of exogenous-triggered change processes should produce different long term outcomes. Where a systemic perturbation may result in rapid policy change, over the long term existing subsystem actors may continue to dominate policymaking. Essentially a perturbation can be 
seen as more of an opportunity for some of those actors to achieve previously-unachievable goals (Howlett and Ramesh 2006, see much of the impact of globalisation in this light). A subsystem spillover will be inherently more complex in that the membership of the policy subsystem (indeed the basic policy domain) is more likely to be permanently altered. Subsystem spillovers will likely introduce powerful new actors into a reformed subsystem leading to unexpected policy squabbles as actors struggle to control the agenda.

Third, in both processes we should see a 'two stage' pattern of response to the exogenous factors. In the first phase the exogenous factors will drive the policy agenda and rapid policy change may occur; however there is an inevitable second phase in which actors in the subsystem settle down into largely endogenous struggles over policy. Here the differences between perturbations and spillovers should be most clear. A spillover, by introducing a wider array of new actors and concerns is more likely to lead to very different normal politics (in which the sector is notable for substantial disagreement over basic policy goals). ${ }^{2}$ After a perturbation, the return to the traditional normal politics should be more predictable. Essentially the second phase in both processes will lead to new normal politics equilibriums, but the equilibrium is harder to predict in the case of a spillover because the policy domain and key subsystem participants have been altered.

The Canadian financial services sector offers evidence of both a subsystem spillover relating to the securitization and globalisation of banking (I987-9I) and a systemic perturbation relating to the current 'crisis of securitization' in international banking (2007-8). These events offer an opportunity to assess the value of the subsystem adjustment concept and whether subsystem spillovers and system perturbations do produce different types of subsystem adjustment. Both illustrate the principal merit of the subsystem adjustment concept: that policy change is still heavily driven by the goals and strategies of actors inside the subsystem - change is endogenous even in these instances.

\section{Financial services globalisation and the deregulation of Canadian banking}

Prior to the Mulroney Conservative Government's decision to deregulate the financial services industry in Canada, the sector was segmented into several different industries. The mortgage and trust industry and the securities industry were provincially regulated and outside of federal jurisdiction. Banking, under the Constitution Act (I982), was a federal jurisdiction. This segmentation, or system of 'pillarization', had been developed to achieve a number of different policy goals - including the availability of ample credit at the local (provincial) level (Harris i999). 
However it also established distinct policy domains for financial services as federal policymaking focused almost exclusively on banking, while policy change in the other sectors was handled by provincial authorities. Thus, prior to deregulation Canada had a federal banking policy subsystem.

Policymaking dynamics in the banking subsystem have been described as 'esoteric' implying a highly closed policy community in which only the leading industry participants, the 'big banks' and the Department of Finance played a significant role in policymaking (Coleman i996). Indeed policy developments were guided by a close set of informal personal relations between industry and government officials (Harris I999) which supported a tight consensus in policy goals. Prior to the late I980s only small changes had been made to the regulatory environment in which banks operated.

However, a series of market developments, many of them exogenous to the Canadian regulatory environment, occurred in the Ig8os which radically recast the policy demands of Canadian banks. First, the nature of lending to corporate clients seeking capital fundamentally changed. With the development of global financial markets, corporations seeking finance were no longer limited to borrowing from a Canadian federally regulated bank - cross border industrial financing boomed in the mid I980s (Lutz 2004). A corporation could now seek lower cost capital in international markets. This development was particularly problematic for Canada's banks as international financial service providers could provide lower cost capital in part due to their ability to avoid domestic regulatory burdens (like reserve requirements which impose a cost on a bank) and in part because many of the providers were 'non banks' offering new 'securitized' forms of capital (Porter, I993, Strange i998, Morris 2004). ${ }^{3}$ Thus domestic regulations like reserve requirements or regulatory rules that prevented banks from becoming more directly involved in the issue, trading and selling of securities had the potential to leave Canada's banks on the sidelines of global finance.

In addition, waves of mergers in the industry elsewhere were rapidly increasing the size of financial services companies. The likelihood that international trade rules would eventually require increased foreign bank access to the Canadian market meant that Canadian banks would eventually face direct competition, even for their domestic client base with these emerging industry behemoths (Williams 2002).

In response to these developments Canadian banks demanded that federal authorities drastically overhaul banking rules. They wanted the right to become directly involved in the (provincially regulated) securities industry. They wanted the right to become major players in the insurance industry. They wanted a reduction in the burden of reserve requirements. 
Finally, they wanted a green light for industry conglomeration as they wished to buy out the major securities and insurance firms and perhaps even merge with one another to produce a small number of globally competitive super banks. In short, they pressured for a major deregulation and policy change in which prudential concerns (relating to the safety and soundness of banks and financial services companies) and issues of domestic industry competition and availability of credit would take a back seat to building Canadian-based global banks. These changes were seen as a necessary response to securitization (Morris 2004). They would also be a massive benefit in the domestic market as the banks' highly developed local branch structure would be a competitive asset if those branches were, under new rules, allowed to sell securities and insurance to bank clients (Tickell I997). While the banks may have wanted these kind of policy changes prior to these international developments, the advent of securitization and globalisation strengthened their hand, making previously unachievable policy goals more plausible.

At the time these demands were pressed in I986 the federal government was in the midst of dealing with two bank failures which raised concerns about the effectiveness of Canadian regulators, a protracted struggle with the provinces over who had the jurisdiction to regulate the financial services sector, and was concerned about Canadian banks' exposure to the LDC debt crisis. Despite these problems, given the existing subsystem dynamics in which the big banks were dominant players, the federal government made an ad hoc series of promises in I987 to deliver on a comprehensive program of deregulation. The government quickly passed legislation allowing federally regulated banks to enter the securities industry, effectively expanding federal jurisdiction over the sector, and promised that in I99 I banks would be allowed similar privileges in regards to the insurance industry. Bank Act changes in 1987 and I99I carried this program into effect. Without delving into the details of the policy struggles involved it is important to recognize that the federal government supported these initiatives because it shared the banks' assessment of the nature of the external challenges - deregulation was seen as necessary to the competitiveness of Canada's leading financial services firms - the big five banks (Coleman and Porter 2003, Darroch 1992, I999 and Roberge 2006). Indeed, on top of industry deregulation, concerns about the inequity and unenforceability of reserve requirements led the government, with little serious discussion, to support the Basel Committee for Banking Supervision's international guidelines which replaced traditional reserve requirements with new, complex capital adequacy standards that effectively lowered the prudential safety net backing Canadian banks' activities (see Porter 1993, or Freedman and Goodlet 1997). 
Post deregulation, banks emerged as the leading players in securitized finance in Canada as they grew rapidly in size and profitability (Canada's banks quickly became the most profitable banks in the world based on returns on equity). However the important point here from the perspective of the subsystem adjustment model is that this history underlines the degree to which the politics of financial services deregulation were never simply a question of 'exogenous shocks' and resulting policy change. The challenges created by globalisation encouraged more cooperation between the government and major private market participants to respond to the changing nature of the sector. Policy responses, however remained very much a question of subsystem dynamics (Roberge, 2006). The banks and the federal government quickly adopted a similar understanding of the problem and a similar set of goals and thus perused one possible set of policy responses. Perhaps more interestingly, the nature of these changes triggered a subsystem spillover which had long term consequences for policymaking in the sector. Deregulation in response to 'globalisation' initiated a second stage response in which its effects subsequently complicated policymaking and led to a period of 'politicization' and inertia in the sector.

\section{Two step internationalization - the subsystem spillover in canadian financial services}

Since the decision to deregulate the financial services industry, policymaking has become far more complex as policy debates became increasingly 'politicized' after i99I (Harris 2004, Williams 2004). Politicization simply denotes the extent to which a number of previously uninvolved, or unimportant, players have emerged as key stakeholders leading to a far more open and public set of policy debates. By precipitously expanding the powers of federally-regulated banks, the federal government blurred the existing policy domains, leading to the creation of a new policy subsystem - a Canadian financial services subsystem which now includes not simply banks, the department of finance and banking issues, but also includes traditionally provinciallyregulated securities and insurance firms, provincial governments themselves and a number of other new players that have taken advantage of the opening generated by the struggles between these different groups to advance their own agendas in the sector. The result has been a kind of policy gridlock in which, despite some relatively small developments, little serious policy change has been possible.

The expansion in the number of subsystem participants generated by the spillover associated with deregulation has been particularly problematic because a number of serious unresolved problems remained post 
deregulation, such as who, or what, would regulate Canada's new securities industry, now dominated by federal banks, what the regulatory demarcation would be between banks and insurance companies, and how much industry concentration would be permitted among banks and among banks and leading insurance companies - the thorny 'mergers question'? On top of this many believed that the Office of the Superintendent of Financial Institutions (OSFI), which was created in I987 to serve as the new prudential regulator of federally-regulated financial services companies, was a weak under-resourced regulator which was not up to the task of regulating the new financial services industry. At the same time, the Bank of Canada has never taken an interest in playing a role in financial services regulation (confidential interviews). None of these concerns have been resolved in the almost twenty years since deregulation, in large part because no consensus has been possible in the new subsystem. ${ }^{4}$

For example, since deregulation there have been consistent concerns amongst bank observers that the standards that insure the capital adequacy of banks are too weak and that there is a need for better prudential regulation (Simmons 200I, Strange, I998), particularly surrounding banks' growing involvement in securities dealing and unsecured derivatives and hedge fund trading. While these concerns seem all too real in light of the ongoing subprime mortgage-generated crisis in the U.S., even prior to this it has been clear that there were large risks in the modern banking environment. For example, several large international banks (including Barings PLG in 1995 and the French bank SocGen in 2007) virtually collapsed as a result of what the industry refers to as 'rogue trading', but which more properly should be seen as problems of insufficient prudential oversight. What is worrying is that in both the Barings PLC and SocGen cases the losses would have represented a significant portion of the total equity of any of Canada's banks. However, Canadian banks and Department of Finance officials have been unwilling to discuss the risks involved in the modern banking environment - despite a similar 'small' recent case in which a 'rogue' securities trader at Toronto Dominion defrauded the bank of \$Ioo million (CDN). Officials have comfortably assumed that Canadian banks are now too big to fail, a common perception in the Canadian industry.

While traditionally-powerful banking sector players like the banks have been unwilling to discuss prudential problems and the need to either ramp up Canada's capital adequacy standards or improve the supervisory capabilities of the OSFI, in the case of securities regulation the problem has been the provinces. During deregulation the federal government promised some sort of plan to regulate the new integrated securities industry, and has continued to pursue a variety of strategies 
to get the provinces to agree to federally-coordinated reform of securities regulation - indeed the federal government would like to assert Constitutional jurisdiction over the sector. ${ }^{5}$ Many believed there was considerable scope for misdeeds in the newly integrated industry (Boreham I990, Babad and Mulroney 1993 and Stewart, 1997). This has been a view shared by consumer groups and industry lobbyists who consistently argue that a single national securities regulator is needed to ensure the safety of investors and of major financial services firms. ${ }^{6}$ Whatever the day to day dynamics of this struggle, the problem is essentially that the federal and provincial governments cannot agree on the creation of a national regulator as the provinces have jealously defended their remaining tenuous control over the securities industry (Roberge 2005).

In the case of questions regarding the demarcation between insurance and banking, the federal government had intended to allow banks not only to own insurance company subsidiaries which they gained the power to do in the 1992 Bank Act changes, but that eventually banks would be allowed to directly sell insurance 'in branch' as they now sell securities. This has not occurred. Insurance companies, eager to defend their turf have become powerful players in the policy subsystem blocking any policy changes which would improve the competitive position of banks relative to insurance companies. Despite several attempts to remove restrictions on banks' insurance dealings, it is still the case that while a bank can sell insurance on line, if a customer is in the branch and wishes to buy insurance from the bank, they must go home and call the bank as these type of sales are still prohibited. ${ }^{7}$

The evidence is similar on the 'mergers question'. While the banks have tried three times since I997 to jump start federal approval for mergers amongst the big five banks, mergers they feel are necessary to be competitive with larger banks elsewhere, these initiatives have also been blocked. In the mergers case, the insurance industry has allied with provincial governments, consumer groups and smaller financial service providers to lobby against allowing 'big to buy big' in the banking sector. Given the unpopularity of the banks (and their record profits and service fees) these groups have succeeded in preventing any federal approval of such an initiative (Williams 2004).

While the banks themselves have become embittered by the 'gridlock' in the sector which is stalling the finishing touches of deregulation, the broader point is that the prospects for serious policy changes of any nature have been poor, This emphasizes the second stage dynamics of a subsystem spillover as the new mix of actors, pursuing competing and irreconcilable agendas have been unable to reach a consensus supporting regulatory reform. ${ }^{8}$ 
The US credit crunch - systemic perturbation and prospects for policy change in Canada

In the race to put a name on the current financial crisis (such as the 'Asian crisis', the 'dotcom crash' etc.), The Economist presciently labeled the fallout of the U.S. subprime mortgage market collapse as the 'first securitization crisis'. 'First' because without regulation it will happen again and 'securitization' because effectively this is the first financial crisis generated by the blurring of the boundaries between the securities industry and the banking industry in the i980's, a blurring that has led to '. . . a complex interdependent system prone to conflicts of interest' in which 'fraud has been rampant' and bankers have been secure in the knowledge that 'someone else - borrowers, investors, taxpayers - would end up bearing at least some of the losses.' (Economist, 'What went wrong', 2008)

For banks, one of the major benefits of deregulation-enabled securitization is that it generated new ways to manage the bank's portfolio flexibly. A bank could offer loans like mortgages to a borrower, then bundle that mortgage into a package of other financial assets, creating asset backed securities (ABS) and then trade or sell these securities to investors, bank clients or other banks. By doing this the pool of credit a bank can offer borrowers becomes much larger, increasing commissions and profits. As the current crisis has shown, other banks would often purchase the ABS to take advantage of short term interest differentials or to use them as security against other financial dealings. The total stock of securitized loans going into the crisis is unknown, but official estimates that they represent as much as USD \$20 Trillion in assets are widely cited by industry participants.

From a regulatory perspective, aside from massively increased complexity involved in banks' trading of these instruments, the major problem is prudential. It is much harder to assess the amount of risk a bank's portfolio is exposed to in this environment. The bank holding the ABS no longer has the same direct relationship with its 'borrowers'. The original issuer of the ABS which perhaps made imprudent mortgage loans in the U.S. market, no longer holds the paper. Instead it is now held by a bank (or for that matter a consumer) that has insufficient information to assess the safety of those loans. Furthermore the bank that now holds the paper can make the situation far worse by borrowing or investing against that 'asset' represented by the ABS. Thus once the ultimate mortgage recipient becomes insolvent, through a chain reaction, a bank which had nothing to do with the original transaction may find itself at risk of collapse - provided its portfolio is not sufficiently diversified or it has insufficient reserves of other kinds of 'liquid assets' - both conditions 
which are no longer ensured in the current loose regulatory framework. These complex arrangements have ensured that the market is unable to self regulate for risk as the distance between borrowers and lenders is so great as to remove incentives for the issuers of ABS to make sure the initial loan is sound (Mian and Sufi 2008).

The collapse of the US asset-backed securities, which initially fell by as much as 40 per cent in value in late 2007 and early 2008, as many US mortgages became untenable, has hit a number of international banks hard as many were operating close to, or below, the lines of international capital adequacy standards (their 'core', or safe, capital comprised of shareholder equity and credit sound loans was too small a percentage relative to the amount of riskier assets they were holding). Ultimately this led banks in the spring and summer of 2008 to huge writedowns, record losses, and in some cases, to collapse.

In the US, for example, Citigroup, once the largest and most profitable bank in the world, posted a staggering $\$ 5 \cdot$ I billion dollar loss in the first quarter of 2008, prompting the bank to lay off over 4 , ooo staff. On top of this the bank was facing the prospect of having to sell off $\$ 500$ billion in assets (almost half its assets under administration) if it hoped to achieve the kind of returns on equity it had prior to the crisis - though it is not clear who will be lining up to purchase the bank's 'underperforming' assets. ${ }^{9}$ Wachovia (the fourth largest bank in the US), posted and even-worse $\$ 8.9$ billion loss in the second quarter of 2008. More widely-publicized, Bear Stearns, a large U.S. investment bank, simply collapsed, requiring a large government financed (USD \$30 billion) takeover. Mortgage finance leaders Fannie Mae and Freddie Mac, responsible for approximately $\$ 6$ Trillion (USD) in mortgages, also required emergency government-funded backing to stay afloat. Worse yet, Indy Mac Bancorp, under FBI investigation for fraud relating to its securities trading, had to be taken over by the Federal Deposit Insurance Corporation as it became insolvent.

At the same time, in Europe, Swiss bank UBS, normally considered a conservative institution focusing on wealth management, managed to lose as much as \$USD 38 billion on American mortgage backed ABS. Subsequent investigation into the bank's books revealed that it was an aggressive expansion into unsecured trading of securities and commodities that led to the bank's improper exposure to the US sub-prime mortgage market. ${ }^{\text {Io }}$ In Britain, Northern Rock's situation was so bad that a partner for a government-financed takeover could not be found in the short term so the bank had to be nationalized. This meant the public was theoretically responsible for Northern Rock's 90 billion pounds in liabilities. ${ }^{\text {II }}$ 
These were not isolated problems. Many major banks had to seek new sources of emergency liquidity to insure their survival. Throughout the summer of 2008, central bankers eager to avoid a complete collapse were forced to inject USD \$roo's of billions in liquidity into markets by temporarily swapping bank assets (like the US-mortgage backed securities) for more liquid assets (like T-bills). This means the risks associated with those assets have in part been temporarily transferred to central banks and perhaps ultimately to taxpayers. ${ }^{12}$

While the crisis is, and was, ongoing the IMF in its April 2008 Global Financial Stability Report, estimated that losses might be as much as \$USD I Trillion, of which bank asset writedowns could be about 7o per cent of that figure. More to the point, as early as the summer of 2008 it seemed likely that the resulting credit crunch was contributing to the onset of a global recession. Perhaps more important than the economic pain, at least from the perspective of the financial services industry, is that the ABS crisis became a powerful symbol of the need for global and national regulatory reform. The failure was framed as systemic. Banks have been shown to have engaged in ridiculously risky activities. Private rating agencies have been shown to be understaffed institutions with little research to back up the solid credit ratings they had been giving ABS and industry/market self regulation appears to be unworkable.

\section{International policy debate in response to the crisis}

In 2005 and 2006 a number of central banks expressed concern with the way that banks were engaged in risky, below appropriate interest rate lending, but with the weakness of the Basel Capital Adequacy Standards, banks were able to hide their level of exposure to risky liabilities off their balance sheets. ${ }^{13}$ Thus once the scope of the problem was revealed in 2007 , and banks required hundreds of billions in liquidity bailouts, policy debate moved quickly towards how to increase the regulatory oversight of global banking to prevent these problems in the future. In October 2007, the $\mathrm{G}_{7}$ asked the world Financial Stability Forum (FSF) to investigate possible reforms to international banking regulations and design a package of reforms which the $\mathrm{G} 7$ could then promote internationally.

The FSF report, released on April in, 2008 (www.fsforum.org) recommended significant regulatory reform. It argued that the Basel Capital Adequacy Standards be amended to require larger capital reserves to offset banks' off balance sheet trading activities and their involvement in ABS. Effectively, the FSF (apparently with the prior agreement of the Basel Committee for Banking Supervision) conceded that the exiting capital adequacy standards were insufficient for the prudent operation of 
banks. The FSF also recommended a host of national accountability and transparency measures to increase the ability of national regulators and bank shareholders to asses the risk level of a bank's portfolio. In particular, the FSF recommended that national regulators as well as industry participants should all strengthen the amount of disclosure surrounding securitized assets to allow more critical assessment. Under the FSF's proposals national regulators should be reformed, giving them greater power to advise bank boards and investors of risky behavior by management.

The FSF also recommended that central banks be given more power to engage in asset swaps to ensure banks have liquidity in times of crisis. In some countries (including Canada and the US) there have been limitations on central bankers' ability to 'swap' assets with a troubled bank to ensure the bank can continue to do business. It seems what the FSF was intending was a more formalized system of 'swap' arrangements, than the ad hoc responses in Britain and the US early in 2008.

The FSF's recommendations echoed much of what has been said by informed observers. Often cited George Sorros, analyzing the crisis, argued that there was a need for better disclosure of banks' financial positions when dealing in the more complex securitized assets, but more importantly that banks should be required to keep larger reserves against risk from involvement in some of the more complex financial instruments currently being traded. ${ }^{14}$ Indeed, the FSF recommendations were rapidly endorsed by the $\mathrm{G}_{7}$ which intended the proposals to prompt national regulatory reforms.

The FSF/G7 assessment of the crisis and its calls for what can only be described as a re-regulation of the global banking industry generated a great deal of 'traction' in policy circles. Several countries rapidly took steps to reform their domestic regulatory structures to improve their ability to monitor banks' behavior. For example, in the US, the Bush administration began to push the 'Paulson Plan' a program put forward by the Treasury Department (which began work on the proposals before the crisis - in early 2007) which proposed a massive overhaul of US financial services regulation. In particular the plan would combine a number of existing regulators under the Federal Reserve Board, which would now have sole responsibility for being a 'market stability regulator', while rules promoting consumer protection, and securities industry conduct would also be tightened (Paulson, 2008). Given the spectacular growth in size of most financial service firms over the last twenty years, the risk of poor firm-specific risk management strategies leading to the collapse of one of these institutions is simply unacceptable in the eyes of many - including those in the industry. Indeed, the current crisis had already (as of August I, 2008) cost the US treasury at least $\$ 70$ billion in 
direct bailouts and several hundred billion in 'stimulus payments' to try to restart the US economy while ensuring liquidity. Thus it was hardly surprising that the crisis generated widespread calls for tighter regulation. ${ }^{15}$ In response to private sector complaints that new regulations were not necessary, even in the troubled US mortgage market, Treasury Secretary Henry Paulson stated simply, 'The world has changed.' ${ }^{16}$ The attitude has been that banks cannot expect \$Ioo's of billions in bailouts without accepting new regulatory oversight to prevent a repeat. Furthermore it is hard for banks eager to avoid new requirements to resist them politically. Even the banks' lobbyists, such as the industry-funded Institute of International Finance, have conceded that banks' existing internal structures are inadequate to prevent unduly risky behavior. ${ }^{17}$

When the crisis subsequently deepened in September of 2008 perhaps one of the worst months ever in the financial services industry policy debate was interpreted by a short term focus on emergency crisis management. When first every major Wall Street investment bank ran into financial problems and second a global liquidity crisis threatened the basic functioning of financial markets, policymakers around the world were forced to focus on the problem of returning liquidity to the market. In the US this meant that discussion of re-regulation took a back seat to the proposed $\$ 700$ billion (USD) Troubled Asset Relief Program 'bail out' of banks while elsewhere policymakers were forced into a variety of liquidity injections to support troubled banks, including in some cases outright nationalization. Nonetheless, as this paper goes to press, markets have stabilized, the US election has been resolved, and attention has quickly returned towards the organization of a major summit to discuss reregulation. While there seems to be an emerging divide between the US and European officials over whether there is a need for a new international regulator of the industry or whether national regulators should coordinate the implementation of tougher national standards, the substance of the policy proposals remains the same. There is widespread support for strengthening capital adequacy standards, transparency mechanisms and clear support for stronger regulation of the types of securities created and traded in financial markets.

\section{Subsystem adjustment in Canada}

In terms of how the crisis has been framed in Canadian circles, it should be noted that the direct financial impact on Canadian banks is still unclear as the full 'bottom line' of ABS writedowns has not been assessed. In Canada trading of ABS related to the US mortgage crisis (referred to as Asset Backed Commercial Paper or 'ABCP') was quickly suspended and the Canadian courts have still not approved an industry lead 
restructuring plan that would resolve the status of the assets. ${ }^{18}$ While Canada's banks were less exposed to the crisis than some American and European banks, there will be 'real pain'. The Canadian Imperial Bank of Commerce (CIBC), one of the 'big five' Canadian banks reported quarterly losses for the first time since the Ig8os LDC crisis after making billions in write downs against devalued ABS it held. Much smaller Coventree Inc, an investment dealer with $\$ 17$ billion in assets under administration, will go bankrupt as soon as legal issues regarding its ABCP holdings are resolved. Despite the more 'muted' nature of the crisis in Canada, the ABCP issue nonetheless exposes, not only prudential problems with banks being engaged in risky activity, but also problems with Canadian securities regulation. Problems which the federal government has been quick to seize on to advance its own policy goals.

Simply, major financial service companies currently hold as much as $\$ 32$ Billion in devalued ABCP. One obvious result of this is that many allege that Canadian regulators, and in particular, the OSFI, should have been monitoring the banks' holdings more closely - that this is evidence of the ineffectiveness of the OSFI as a prudential regulator. These allegations prompted the OSFI to 'pass the buck', as the current superintendent publicly complained that some aspects of managing the $\mathrm{ABCP}$ problem were not in her jurisdiction and that those concerns should have been handled by the Ontario Securities Commission (DeCloat 2008). In testimony before the House of Commons Finance Committee, she frustrated MP's by blithely insisting on the one hand that because no major bank had collapsed that everything was working fine, while on the other hand suggesting the problem areas were outside of her jurisdiction. Essentially the OSFI argued that the crisis involved 'nonbank' activities of banking(!) ; which highlights the regulatory lacunae left over by deregulation in Canada. ${ }^{19}$ It is not clear, even to the regulators themselves, who is responsible for maintaining the soundness of Canadian financial institutions engaged in securities trading. Many Canadian investors had bank-run securities firms recommend ABCPs to them. Facing the prospect of those assets being lost, many launched complaints with the Banking Ombudsman and with the Investment Dealers Association. As has been noted by bank critics for some time, there is little regulation in place to prevent banks from passing along risky securities to their own securities clients which in turn limits the bank's exposure to losses (Stewart 1997). Politics aside, it is hard for many observers to not see this crisis as evidence that not only does Canada need a stronger prudential regulator than the OSFI, but that the absence of a national securities regulator which sets clear rules governing how firms trade and sell securities must be sorted out - even the regulators seem to agree. 
Finally, the crisis generated some concern about the Bank of Canada's (BoC) ability to affect monetary policy. In part driven by the desire to limit growth in the value of the Canadian dollar and head off a recession in Ontario, and in part to ensure the credit crunch does not stifle economic growth the $\mathrm{BoC}$ has made a number of interest rate cuts since the Fall of 2007. However, private lenders who have usually moved lock-step with BoC changes, did not follow the Bank's lead in both the Spring and Fall of 2008. Exposed to potential writedowns on ABCP, Canada's banks have wanted to keep lending rates higher to limit the impact of their loses on their overall financial position. This prompted Bank of Canada Governor, Mark Carney, to publicly question the effectiveness of the BoC's control over Canadian monetary policy. ${ }^{20}$

Thus, there has been a marked 'change in tone' in Canada as elsewhere as it is hard to escape the conclusion that the crisis shows the need for clearer international and domestic regulations to manage risky behavior by financial services companies. Indeed, federal officials led by Finance Minister Jim Flaherty have seized on the crisis to advance their own pre-existing agenda for strengthening the federal government's control over the sector. Thus much like the earlier perturbation that led to deregulation in Canada, in this instance leading actors in the policy subsystem have seen the exogenous developments as an opportunity to advance previously unachievable policy goals.

As an example, in response to the $\mathrm{G}_{7}$ endorsement of the FSF proposals to tighten national regulatory requirements for banks, in particular that national prudential regulators be given more power to investigate bank's asset sheets, Flaherty called an extraordinary summit of leading stakeholders in Canadian financial services in late April to discuss policy reform (Perkins and Carmichael 2008b). Mirroring the older, pre-deregulation policymaking style, the summit included only the most powerful participants, the Finance Minster, the Bank of Canada Governor, the head of the OSFI and the heads of only Canada's largest financial services companies. The Canadian Bankers Association publicly tried to frame the meeting as an information session since Canadian banks were 'in good shape' and already responding to the situation (Perkins 2008). Some complained that the minister was making a too public-show of the event; however this underlines how serious Flaherty has been about using the $\mathrm{G} 7$ initiative as a platform to close some of Canada's longstanding regulatory problems and expand his own jurisdiction. Behind closed doors, Flaherty used the meeting to discuss new disclosure regulations, while in public he used the meeting as a platform to re-launch Federal plans for a National Securities Regulator - an initiative that has gone almost nowhere since 2000. 


\section{Policy change}

While it is early to speculate on the full scope of reforms that will be enacted in response to the crisis, a number of initiatives already seem clear. Firstly, the government has already committed to 'ramping up' the effectiveness of the OSFI, as the Superintendent has recently released plans to significantly expand staff levels to improve its ability to investigate things like risky commercial paper dealing and how such behavior may be affecting federally-regulated institutions soundness (OSFI 2008). Second, the government has also announced new, tighter regulation of banks' dealing of Principle Protected Notes (PPN's). PPN's are baskets of financial instruments (stocks, commodities etc.) sold to an investor in which the bank guarantees that the investor will not lose money on the asset. Obviously such assets have recently become more popular as an investment 'safe haven', but there has been no regulatory oversight of these assets. PPN's are extremely complicated instruments for purchasers to assess, particularly since there is no effective requirement that banks disclose the nature of the underlying assets being sold to investors. There have also been concerns expressed that there is no regulation of the commissions and fees charged by the bank. ${ }^{21}$ Given lessons from ABCP dealing the Finance Minister has promised rules to regulate the dealing in these type of notes. Regulations had been proposed in the past, but only after use of the instruments swelled in the sub-prime mortgage crisis has the Department of Finance delivered on a package of rules that are to become effective on July I, 2008. Canada's banks have publicly endorsed the initiative.

On securities regulation, Flaherty's position throughout the crisis has been that it directly illustrated the need for tighter national regulation of the securities industry. In his public comments, Flaherty has noted that he is in a particularly weak position relative to other countries to prevent such problems as he is one of the few finance ministers that does not have control over the regulation of that industry - even though the major industry players that might be undermined by riskier behavior are federally-regulated and insured institutions. ${ }^{22}$ In February, Flaherty had tried to restart national securities regulation harmonization proposals by appointing a panel to seek simplified rules. He used the summit in response to the $\mathrm{G}_{7}$ initiative to try to drum up additional support. Indeed, the prognosis for major federal-led-securities-regulation-reform is better than it has ever been as support seems to have grown for a national regulator. Flaherty's position has received support from the Liberal opposition in Ottawa and from some provincial players as well. For example, in April the Ontario Attorney General's office proposed expanding its role in prosecuting illegal financial activities, directly 
suggesting that the Ontario Securities Commission (OSG) was an ineffective regulator. ${ }^{23}$ This may signal a change in policy in Ontario, in which perhaps the OSC's status as a virtual national securities regulator might no longer be as important to the province as preventing financial crime. It could help pave the way for a deal on securities regulation in which the federal government ends up in the driver's seat. ${ }^{24}$ Likewise both industry participants, and the International Monetary Fund (IMF) have lent support to creating a single national securities regulator in Canada. Amidst the crisis, the IMF released a report on Canada's financial system arguing for a national securities regulator while lamenting the absence of any serious criminal apparatus to deal with financial crime (IMF 2008a). This report built on earlier IMF analyses that have often singled out Canada as a particularly weak regulatory of illegal financial services activities. Throughout the fall, an Expert Panel on Securities Regulation, established by Flaherty has been refining legislative proposals for strengthening the national regulator. Given the deepening of the financial crisis over those months and the support leant to the process by the Bank of Canada a national regulator seems a possibility for the first time. ${ }^{25}$

Finally, as part of the 2008 budget implementation legislation (Bill C-5o) the government hurriedly inserted and passed with little scrutiny legislation that amended the Bank of Canada Act, giving the Bank of Canada $(\mathrm{BoC})$ more power and a more direct role in managing this type of financial crisis. The new rules allow the BoC to accept a wider array of financial instruments as deposits from banks. The intent of the rule changes is to give the BoC more flexibility in responding to a crisis at one of Canada's banks by being able to swap risky securities threatening the collapse of a bank for a more safe asset - as was suggested by the $\mathrm{G}_{7}$ /FSF proposals. The changes make it easier for the BoC to bail out a bank; however they also mean that the BoC could theoretically find itself exposed to the kind of ABS meltdown we have just gone through, perhaps requiring its own taxpayer-funded bailout. ${ }^{2}$

The net effect of the current perturbation might well be to resolve some of the policy problems left unresolved by the last major perturbation in Canadian financial services, highlighting the extent to which serious policy change is ultimately sparked by exogenous factors. Nonetheless, consistent with the subsystem adjustment concept it is already clear that preferred paths of policy change are being selected by actors in the existing subsystem. At the very least the crisis has strengthened the hand of the federal government in pursuing stronger national institutions to regulate finance. Indeed, at the same time that the Federal government is arguing for expanded federal control over the sector, it has argued in international forums that there is not a need for a new international 
banking regulator to set more uniform standards. ${ }^{27}$ The apparent hypocrisy in this position is best explained by the extent to which leading subsystem participants in Canada see the crisis as an opportunity to achieve pre-exiting policy goals. Policy change in the Canadian context remains very endogenous.

Globalisation of financial services in many other jurisdictions has tended to result in centralization of jurisdiction and regulatory responsibility (Lutz 2004. Roberge 2005) and the current crisis is likely to accentuate that trend, particularly in Canada.

\section{Conclusions}

Two lessons can be drawn. First, while the spark that starts policy change processes in both systemic perturbations and subsystem spillovers is exogenous to the existing subsystem, in both cases policy change itself is still largely influenced by factors normally thought to be endogenous to the subsystem, the policy goals and strategies of key actors. In this sense the subsystem adjustment concept offers an important corrective to the tendency to treat exogenous shocks as complete breaks from normal policymaking considerations in a sector. Second, careful effort needs to be made to distinguish systemic perturbations from subsystem spillovers as they generate different dynamics over the long term. Various types of exogenous systemic perturbations have been seen as the most common explanation of periods of policy change since Hall (I993), but far more attention is needed to document the differences between these processes and to develop hypotheses about their likely impact.

In particular, subsystem spillovers associated with factors like globalisation, need to be seen as a more specific category of exogenous perturbation. The principal difference lies in the extent to which the policy response to the exogenous shock results in substantial alterations to the existing policy domain. In a subsystem spillover of the type which occurred during the deregulation of financial services in Canada, the result will be the entrance of new actors and new policy goals into a reformed policy subsystem. Such a situation over the long term will produce more confused policy struggles, lead to considerable inertia in policy in the second stage of adjustment to the exogenous change, and perhaps ultimately undermine the power of existing players to dominate policy outcomes. A systemic perturbation that does not challenge the boundaries of the existing domain, will generate different dynamics. The major effect of the current crisis of securitization has been to strengthen the position of the federal government in policy debate. Whatever the ultimate regulatory changes in response, they are unlikely to expand the policy domain. The current crisis has improved the Finance Minister's 
ability to pursue pre-existing policy goals of asserting federal jurisdiction over the industry. The resulting phase two, the 'normal politics' of this sector, should reflect that fact.

\section{Acknowledgements}

\section{The author would like to thank Colin Bennett for his comments on an earlier version of this paper as well as the anonymous reviewers of the Journal. This research was conducted with the financial support of the Social Science and Humanities Research Council of Canada.}

\section{NOTES}

I. Clark was speaking at a conference hosted by the Swiss Bank UBS which has lost as much as $\$ 37$-billion (U.S.) in writedowns associated with the fallout from the US subprime mortgage crisis. Quoted in Perkins (2008b).

2. Howlett and Ramesh's reasoning on these spillover-specific phase two effects needs further development. While they correctly suggest that in phase two 'stability processes' will trounce 'change processes' and normal policy making will once again become more incremental, they do not fully tease out hypotheses about what this normal politics equilibrium might look like. However, logically, collapsing the boundaries of previously discrete subsystems governed by different policy paradigms should produce a particular pattern of normal politics; one in which inertia is more likely because the number of 'veto players' will have increased, and because significant confusion may exist for some time about basic policy goals.

3. Narrowly, the process of securitization refers to the creation of financial products that combine a range of financial assets for direct marketing to clients as securities. In international banking this term is used to describe banks' diversification of their product base to include these forms of financial instruments. Securitized assets can be sold to clients generating a larger pool of capital that might be available from traditional bank deposits. Securitization allowed traditional banks to compete with the emerging international securities trading sector for example Wall street 'investment banks'). However, this blurring of the boundaries between the securities industry and banking has important implications. Traditionally banks intermediated between lenders and borrowers. Banks lent money to borrowers without depositors directly risking their savings. Securitized finance is disintermediated as the purchasers of the securities are effectively lending money directly to the issuer of the security. Unlike traditional banking, their own money is directly at risk. While securitization was good for banks - banks gained assets under administration, generated profits from commissions on the sale of securitized assets and avoided the costs of traditional reserve requirements - securitization created new risk for consumers of financial services.

4. It should be noted that these remaining regulatory 'problems' in Canada were not unique. European regulatory reform also proved difficult given the post-I99os deregulation complexities of a globalised industry and multilevel governance. See for example De Visscher, Maiscocq, and Varone (2008).

5. When the federal government allowed federally-regulated banks into the securities business they claimed the Constitution was fuzzy on the issue. Federal authorities maintain to this day that the Constitution could actually be interpreted as giving the federal government the power to regulate the sector. See Gray and Kitching (2005).

6. See for example, PDAC, 'Position on securities reform in Canada (May 2005)', www.pdac.ca

7. Because of the continued regulatory impasse the banks have had to restructure the physical architecture of their branches to be able to provide insurance, if not 'in branch' then 'adjacent to the branch'. RBC, eager to get into the $\$ 3$ trillion $(\mathrm{CDN})$ consumer insurance industry has begun to open conjoined RBC bank and RBC insurance branches. Under this system a customer in the bank branch can be asked to step through the doors into the adjacent insurance branch, if they wish to purchase an insurance product. See Globe and Mail, Report on Business 
Weekend, Saturday, April 26, 2008. These developments have been discussed for some time by banking industry lobbyists, though most expected the regulatory obstacles would be removed sometime ago, preempting the need for the special branches (Source: Confidential Interviews).

8. Much of banks' frustrations stems from their belief that they mistakenly 'bet' on domestic deregulation and conglomeration as a business strategy, but the government never fully delivered on the promises of the deregulatory period (Source: Confidential interviews).

9. Citigroup's financial problems have been well documented in the business press. See for example Read (2008).

Io. Economist, 'Wealth mismanagement,' April 24, 2008.

I I. At the point it was nationalized, Northern Rock already had been loaned 25 billion pounds by the British Treasury to stay afloat. The nationalization has resulted in 90 billion pounds of private debt being transferred to taxpayer-funded public debt at least for the time being.

I2. Economist, 'Providing Cover', April 21, 2008.

I3. While this was once an allegation made only by critical scholars, and widely ignored by policymakers, it is now an accepted fact in the industry that the old standards did not work to ensure prudential goals. See for example, The Economist, 'Bank Capital: Joseph and the amazing technicalities,' April 24, 2008.

I4. See interview: 'Euro can't replace greenback: Soros' Reuters, April I7, 2008.

I5. This is clear in the business press for example. Sources usually notable for the pro-market, pro deregulation orientations to financial services, have rejected banks' calls for more self regulation and voluntary codes as a way to prevent a repeat of the crisis as insufficient. Indeed, banking industry lobbyists have been sidelined in both the $\mathrm{G}_{7}$ discussions and the debate about regulatory reform in the US. While complaining that new regulations were unnecessary, the debate simply moved past them. See for example, Drohan (2008), Perkins and Carmichael (2008), and McKenna (2008).

I6. Quoted from McKenna (2008).

17. See for example Institute of International Finance, Final Report of IIF Committee on Market Best Practices - Principles of Conduct and Best Practices Recommendations, July 2008.

I8. This has understandably reinforced a sense that 'everything is all right in Canada'. Although, the important point from a regulatory perspective is that there were no limits in place which would have prevented Canadian banks from over-exposing themselves to US mortgage backed securities as other banks did. It was simply lucky that they did not.

19. See Standing Committee on Finance, Evidence, Monday June I6, 2008. House of Commons, 39th Parliament, 2nd Session.

20. See Carney's testimony to the Senate Banking Committee, Standing Senate Committee on Banking, Trade and Commerce, Evidence, May I, 2008. Senate, 39th Parliament, 2nd Session.

21. See for example, Carmichael (2008).

22. For Flaherty's most pointed comments on the issue see, Perkins (2008c).

23. See for discussion, Howlett and Macfarland (2008).

24. In the meantime, provincial securities regulators have been all to silent on the issue - in large part because their handling of the ABCP issue illustrates that a national regulator is needed and that the defense of provincial jurisdiction has been a mistake. For example, the Ontario Securities Commission removed existing restrictions on ABCP dealing in 2005, in large part because several smaller provinces had no rules. Provincial control over securities rules effectively means no rules. Defending this status quo is not a winning argument in the current crisis.

25. Recently retired Bank of Canada Governor David Dodge, echoing Alan Greenspan's mea culpa that central bankers had put to much faith in self regulation, has publicly argued that some of the securities being traded by banks are 'ridiculous' and leant his support to tougher regulation of the industry in Canada. See McNish (2008). While the bank of Canada has tried to officially avoid taking sides on the national regulator debate, the current governor has consistently argued that the status quo is unacceptable.

26. There is considerable confusion about the meaning of this initiative as some have misconstrued this change as not simply being an attempt to widen the crisis management tools of the bank. See for example, Schoffield (2008). However, the context is clear. Officials in the US and Britain have both found it necessary to temporarily swap asset backed paper held by banks for safer instruments to insure that those banks remain liquid. The BoC has done likewise offering about CDN \$4 billion in these type of swaps. Clearly the bank would like the latitude to do more in the event that one of Canada's big banks' was facing a Bear Stearns-like situation. 
27. Canada's government has publicly argued against European proposals for a new international banking regulator. See, McCarthy (2008).

\section{REFERENCES}

Babad, M. \& Mulroney, C. (I993), Pillars: The Coming Crisis in Canada's Financial Industry. Toronto: Stoddart.

Baumgartner, F. \& Jones, B. (I993), Agendas and Instability in American Politics. Chicago: University of Chicago Press.

Baumgartner, F. \& Jones, B. (I99I), 'Agenda dynamics and policy subsystems.' fournal of Politics, Vol. 53. Issue 4. Pp. I044-I075.

Bennett, C. (I99I), 'How States Utilize Foreign Evidence' Journal of Public Policy. Vol. ir. Pp. 3I-54.

Bernstein, S. \& Cashore, B. (2000), 'Globalisation, Four Paths of Internationalization and Domestic Policy Change: The Case of Eco Forestry in British Columbia.' Canadian Fournal of Political Science. 33.

Boreham, G. (I990), 'Three Years After Canada's 'Little Bang'.' Canadian Banker. September/ October, I990. Vol. 97. Issue 5.

Carmichael, K. (2008), 'Flaherty closes in on new PPN rules.' Globe and Mail, Report on Business. May 9. Coleman, W. (1996), Financial Services, Globalisation and Domestic Policy Change, London: Macmillan, I996.

Coleman, W. \& Perl, A. (I999), 'Internationalized Policy Environments and Policy Network Analysis.' Political Studies. September. Vol. 47. Issue 4.

Coleman, W. \& Porter, T. (2003), 'Playin' Along: Canada and Global Finance.' in Wallace Clement \& Leah Vosko, eds. Changing Canada: Political Economy as Transformation. Montreal and Kingston: McGill-Queen's University Press. pp. 24I-264.

Darroch, J. (I992), 'Global Competitiveness and Public Policy: The Case of the Canadian Multinational Banks.' Business History. 34:3 (July I992) pp. I53-175.

Darroch, J. (I999), Canadian Banks and Global Competitiveness. Montreal \& Kingston: McGill-Queen's University Press, I999.

DeCloet, D. (2008), 'Watchdog could use some more Bay Street bite'. Globe and Mail, Saturday, April 26 , p. B 2 .

De Visscher, C., Maiscocq, O. \& Varone, F. (2008), 'The Lamfalussy Reform in the EU Securities Markets: Fiduciary relationships, Policy Effectiveness and Balance of Power.' Journal of Public Policy, 28. I. pp. $19-47$.

Drohan, M. (2008), 'In praise of (some) regulations.' Globe and Mail, April io.

The Economist (2008), 'What went wrong,' May i9.

The Economist (2008), 'Wealth mismanagement,' April 24, 2008.

The Economist (2008), 'Providing Cover', April 2i, 2008.

The Economist (2008), 'Bank Capital: Joseph and the amazing technicalities,' April 24, 2008.

Freedman, C. \& Goodlet, C. (1997), 'The Financial Services Sector: Past Changes and Future Prospects.' Background Paper for the Ditchley Canada Conference, Toronto ON, 3-5 October.

Gray, T. \& Kitching, A. (2005), Reforming Canadian Securities Regulation. Library of Parliament PRB 05-28E, September I9.

Hall, P. (I993), 'Policy Paradigms, Social Learning and the State.' Comparative Politics. 25(3). Pp. $275^{-296 .}$

Harris, S. (I999), 'The Globalisation of Finance and the Regulation of the Canadian Financial Services Industry.' in G. Bruce Doern et al. Changing the Rules: Canadian Regulatory Regimes and Institutions. University of Toronto Press, I999, pp. 36r-38I.

Harris, S. (2004), 'Financial Services Reform in Canada: Interests and the Policy Process.' Canadian fournal of Political Science. March 2004. pp. I6I-I84.

Heclo, H. (I974), Modern Social Politics in Britain and Sweden: From Relief to Income Maintenance. New Haven: Yale University Press.

Howlett K. \& Macfarland, J. (2008), 'Ontario vows greater role in prosecuting securities cases.' Globe and Mail Report on Business. April $\mathrm{I} 8$.

Howlett, M. \& Cashore, B. (2007), 'Punctuating Which Equilibrium? Understanding Thermostatic Policy Dynamics in Pacific Northwest Forestry.' American fournal of Political Science. Vol. 51. No. 3. July 2007, Pp. 532-55I.

Howlett, M. \& Ramesh, M. (2002), 'The Policy Effects of Internationalization: A Subsystem Adjustment Analysis of Policy Change.' Journal of Comparative Policy Analysis; Research and Practice. 4. Pp. $3^{\mathrm{I}-5 \mathrm{O}}$. 
Howlett, M. \& Ramesh, M. (2006), 'Globalisation and the Choice of Governing Instruments: The Direct, Indirect, and Opportunity Effects of Internationalization,' International Public Management fournal. 9(I). pp. I-20.

International Monetary Fund (2008a), Canada - Financial System Stability Assessment-Update. Prepared by the Monetary and Capital Markets Department, Approved by Jaime Caruana and Anoop Singh, January I5.

International Monetary Fund (2008b), Global Financial Stability Report - Containing Systemic Risks and Restoring Financial Soundness (April 2008). Washington: International Monetary Fund.

Institute of International Finance (2008), Final Report of IIF Committee on Market Best Practices - Principles of Conduct and Best Practices Recommendations. July 2008. (www.iif.com)

Lutz, S. (2004), 'Convergence Within National Diversity: The Regulatory State in Finance.' Journal of Public Policy. 24, 2, pp. I69-197.

McCarthy, S. (2008), 'Harper Lines up with Bush on reform.' Globe and Mail, November I7.

McKenna, B. (2008), 'Even on Wall Street, Capitalism takes a hit.' Globe and Mail, Report on Business, March 27.

McNish, J. (2008), 'Central Bank saw disaster coming.' Globe and Mail, September ı2, 2008.

Mian, A. R. \& Sufi, A. (2008), 'The Consequences of Mortgage Credit Expansion: Evidence from the 2007 Mortgage Default Crisis.' (January I, 2008). Available at SSRN: < http://ssrn.com/abstract= I072304>

Morris, T. (2004), 'Bank Mergers Under a Changing Regulatory Environment.' Sociological Forum. Vol. I9, No. 3. September. pp. $435-463$.

Nohrstedt, D. (2008), 'The Politics of Crisis Policymaking: Chernobyl and Swedish Nuclear Energy.' Policy Studies fournal. Vol 36. No. 2. Pp. 257-278.

OSFI (2008), Plan and Priorities 2008-2II.<http://www.osfi-bsif.gc.ca >

Paulson, H. (2008), The Department of the Treasury Blueprint for a Modernized Financial Regulatory Structure. The Department of the Treasury, March 2008.

Perkins, T. (2008), 'Credit Crunch must be monitored closely, Flaherty says.' Globe and Mail. April 28.

Perkins, T. (2008b), 'Commodity prices too pumped, TD warns.' Globe and Mail, May I3.

Perkins, T. (2008c), 'Ottawa looks to boost securities regulation.' Globe and Mail, April io.

Perkins, T. \& Carmichael, K. (2008), 'More Rules? No thanks, banks say.' Globe and Mail, April 9.

Perkins, T. \& Carmichael, K. (2008b), Financial summit tackles credit crunch.' Globe and Mail, April 28.

Porter, T. (1993), States, Markets and Regimes in Global Finance. St. Martin's Press.

Quaglia, Lucia (2008), 'Explaining the reform of banking supervision in Europe: An integrative Approach.' Governance. Vol. 2i. Issue 3. Pp. 439-463.

Read, M. (2008), 'Citigroup to sell \$50o-billion in assets.' Globe and Mail, Report on Business, May 9.

Roberge, I. (2005), 'Fighting the Joint Decision Trap: Canadian Regulations in the Securities Industry,' Paper presented to the Canadian Political Science Association, London Ontario, May.

Roberge, I. (2006), 'Middles-Sized Powers in global Finance - Internationalisation and domestic policy-making' Policy Studies, Vol. 27, No 3. pp. 253-270.

Sabatier, P. \& Weible, C. (2007), 'The Advocacy Coalition: Innovation and Clarifications.' In Theories of The Policy Process, 2nd Ed. Paul Sabatier, ed. Boulder: Westview Press.

Simmons, B. (200I), 'The International Politics of Harmonization: The Case of Capital Market Regulation.' International Organization. 55. 3. pp. 589-620.

Schoffield, H. (2008), 'Central bank moves to accept new risks.' Globe and Mail, April 2.

Skogstad, G. (2000), 'Globalisation and Public Policy: Situating Canadian Analyses.' Canadian Fournal of Political Science. XXXIII:4. December. pp. 805-828.

Stewart, W. (I997), Bank Heist: How Our Financial Giants Are Costing You Money. Harper Collins, I997.

Strange, S. (I998), Mad Money. When Markets Outgrow Governments. Ann Arbour: University of Michigan Press.

Tickell, A. (I997), 'Restructuring the British Financial Sector into the twenty-first Century.' Capital and Class. Summer. Issue 62. pp. I3-20.

Williams, R. (2004), 'Mergers if Necessary, but not Necessarily Mergers: Competition and Consolidation at Canada's 'Big Banks'.' in R. Campbell, L. Pal \& M. Howlett eds. The Real Worlds of Canadian Politics, Cases in Process and Public Policy, Fourth Edition. Toronto: Broadview Press. pp. I55-2I4.

Williams, R. (2002), ' "Liberalizing Trade in Services": Ideas in International Political Economy.' in McBride, Dobuzinskis, Cohen, and Busumtwi-Sam eds. Global Instability. Kluwer. pp. 65-88. 
RUSSELL ALAN WILLIAMS

Assistant Professor

Department of Political Science

Memorial University of Newfoundland

St. Fohn's NL, Canada, $A_{I} B_{3} X_{9}$

Phone: 709-737-4402

Fax: o9-737-4000

E-mail:russellw@mun.ca 